\title{
非代償性肝硬変の難治性腹水に 茵蔯蒿湯合五苓散料が奏効した一例
}

角藤 裕 清水 元気 山岡傳一郎 愛媛県立中央病院漢方内科，愛媛， =790-0024 松山市春日町83

\section{A Case of Refractory Ascites with Liver Cirrhosis Successfully Treated by the Combination of Inchinkoto and Goreisan (Inchinkoto-Go-Goreisan)}

\author{
Hiroshi KAKUTO Genki SHIMIZU Denichiro YAMAOKA
}

Department of East Asian Traditional Medicine Ehime Prefectural Central Hospital, Kasuga-machi, 83 Matsuyama, Ehime 7900024, Japan

\begin{abstract}
We report on a case of ascites with liver cirrhosis due to hepatitis B virus (HBV) that was successfully treated with a combination of inchinkoto and goreisan (inchinkoto-go-goreisan). Our patient, a 58-year-old woman had neglected her chronic B hepatitis and diabetes mellitus, and had not been treated with medication. She was admitted to our hospital because of severe jaundice and the ascites, which were noted when she consulted us for traumatic neck pain. Though we administered human albumin with diuretics, e.g. the combination of furosemide and spironolactone, the ascites did not improve. After administering a combination of inchinkoto and goreisan decoction, however, the ascites decreased rapidly within a month. In this case, we found that an inchinkoto-go-goreisan decoction was more effective than an inchinkoto decoction or a goreisan extract. This suggests that the effects of Gardenia and Rheum they are made from can be significant.

Key words : ascites, jaundice, liver cirrhosis, inchinkoto, goreisan

要旨

B 型肝炎に伴う非代償性肝硬変により生じた治療抵抗性の腹水に対し茵陳蒿湯と五苓散料が奏効した一例を経験 した。症例は58歳女性。B 型慢性肝炎と糖尿病を無治療で放置しており, 外傷に伴う頸部痛で受診した際に黄疸と 腹水を指摘され入院した。フロセミドやスピロノラクトンといつた利尿薬の効果に乏しく, アルブミン補充でも腹 水のコントロールが不良であったが, 茵陳藁湯合五苓散料を煎薬にて投与したところ 1 カ月余りの間に速やかに改 善した。茵陳五苓散料（煎薬）あるいは五苓散エキスと比較し明らかに効果があったと思われ，特に山栃子や大黄 の作用が重要であったと考えられた。
\end{abstract}

キーワード : 腹水, 黄疸, 肝硬变, 茵陳藁湯, 五苓散

\section{緒言}

B 型慢性肝炎から肝硬変へと進行し，非代償期に なると低アルブミン血症，腹水貯留，黄疸が出現す るようになる。現在 B 型肝炎ウイルスに対しては 抗ウイルス薬や PEG-IFN など有効性に優れた治療 法が開発されているが, 非代償期の腹水や黄疸に対 する優れた治療法は確立していない。今回, B 型肝 炎による非代償性肝硬変に伴う難治性腹水に対し, 茵蔯蒿湯合五苓散料の煎じ薬が奏効した一例を経験 したので, 若干の考察を加えて報告する。

\section{症例}

患 者: 58歳 女性

主 訴: 頸部痛, 腹部膨満感

既往歴：糖尿病, B 型肝炎

家族歴：特記事項無し

現病歴: $\mathrm{X}-5$ 年頃から糖尿病と B 型慢性肝炎を 他院で指摘され，一時期治療を受けていたが自己判 断で中断し放置されていた。 X-1 年11月末, 自宅 にて転倒して側頭部を打撲し当院を受診された。頚 椎捻挫を疑われ対症療法の方針となっていたが，こ 


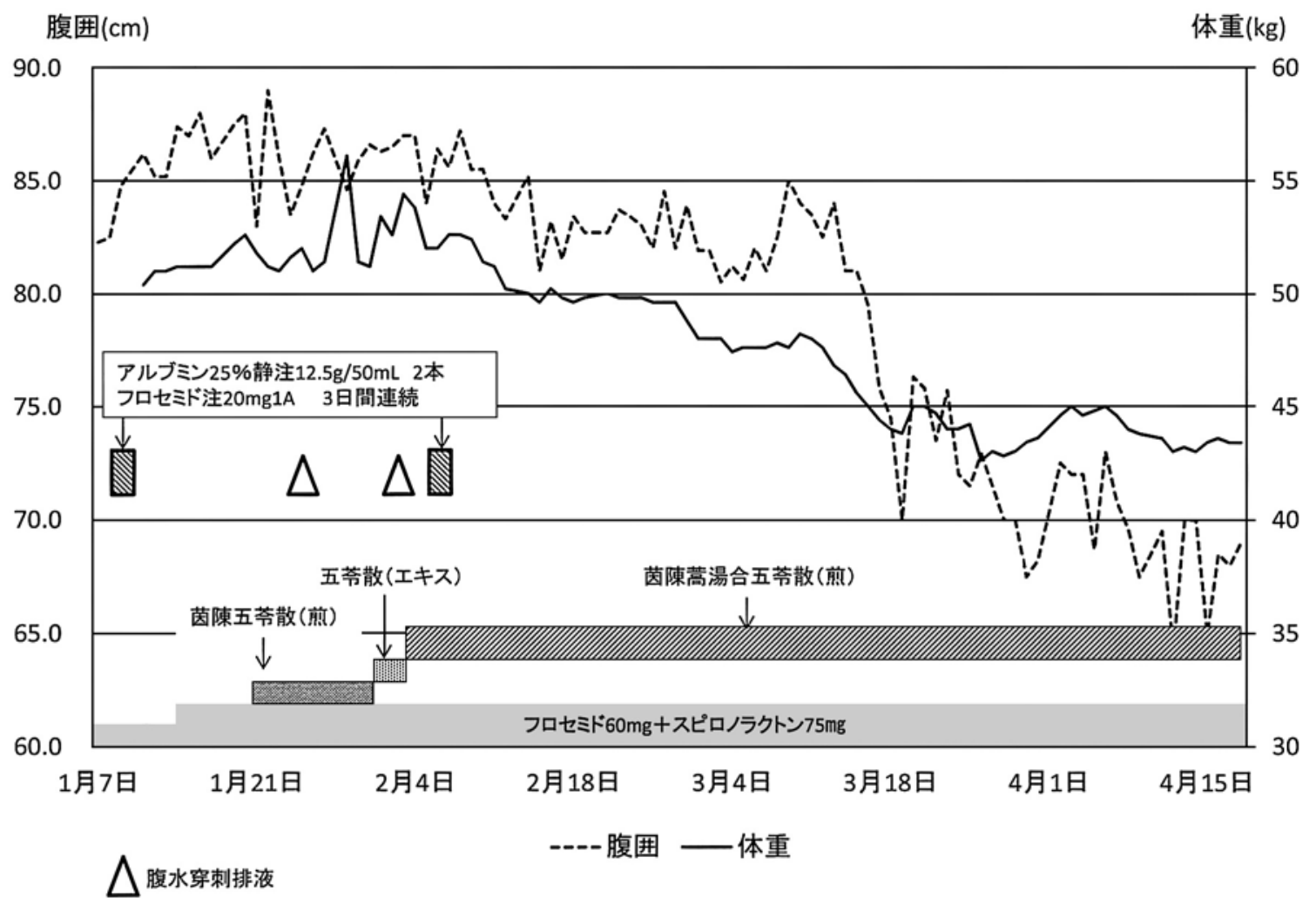

図 1 腹囲と体重の経過

入院中の腹囲と体重の推移を図に示す。茵蔯蒿湯五苓散料を投与開始後，徐々に腹水と体重が減少し た。

の時点で明らかな黄疸と腹水を認め，また $\mathrm{HbAlC}$ (JDS） $8.2 \%$ と高血糖も合併しており $\mathrm{X}$ 年 1 月 4 日緊急入院となった。インスリン導入およびエンテ カビルを開始した。メチシリン感受性黄色ブドウ球 菌（MSSA）による化膿性脊椎炎を合併しているこ とが判明し抗生剂治療を併用した。合併する肝硬変 については，入院時より水分と塩分制限をし，フロ セミド $60 \mathrm{mg} /$ 日とスピロノラクトン $75 \mathrm{mg} /$ 日の内 服併用で利尿を試みたが, 低 Alb 血症と低 $\mathrm{Na}$ 血症 が進行し改善が得られなかった。随時腹水穿刺排液 を試み，またアルブミン $25 \% 50 \mathrm{ml} \times 2$ 本とフロセ ミド $20 \mathrm{mglA}$ の点滴を 3 日間投与しても改善しない ため，漢方薬を考慮することとした。

西洋医学的所見: 意識清明, 見当識障害なし。血 圧 $155 / 75 \mathrm{mmHg}$ 。全身に黄疸を認め, 腹水著明。 心音・呼吸音は異常を認めなかった。顔面及び体幹 に毛細血管拡張, 及び手掌紅斑を認めた。四肢浮 腫なし。体重 $50.4 \mathrm{~kg}$, 腹囲 $86.2 \mathrm{~cm}, \mathrm{TP} 9.0 \mathrm{~g} / \mathrm{dL}$, ALB $1.6 \mathrm{~g} / \mathrm{dL}, \quad$ T-Bil $3.2 \mathrm{mg} / \mathrm{dL}, \quad$ D-Bil $2.4 \mathrm{mg} / \mathrm{dL}$, AST $48 \mathrm{IU} / \mathrm{L}$, ALT $26 \mathrm{IU} / \mathrm{L}$, ChE $51 \mathrm{IU} / \mathrm{L}, \gamma-\mathrm{GT}$ $212 \mathrm{IU} / \mathrm{L}, \quad$ BUN $19.0 \mathrm{mg} / \mathrm{dL}, \quad \mathrm{Cr} 0.45 \mathrm{mg} / \mathrm{dL}, \quad \mathrm{Na}$
$120 \mathrm{mEq} / \mathrm{L}, \quad \mathrm{K} 4.0 \mathrm{mEq} / \mathrm{L}$ 。

漢方医学的所見：中肉中背の女性であるが腹部は 膨満し蛙腹。全身に黄㾝あり顔面に細絡が目立つ。 舌は歯痕なし, 暗赤色, 舌苔薄い。舌の静脈怒脹な し。脈は沈で有力。便秘気味。

経 過: 黄疸と腹水の所見から, 茵蔯五苓散料 （煎じ薬）を考えX 年 1 月21日より投薬を開始し た。その後患者からエキス剤への変更の要望があり 1 月28日より五苓散エキス（ツムラ， $7.5 \mathrm{~g} /$ 日）と したが特に変化は見られなかった。便秘を合併して いることから，下剤の入った処方を考え 2 月 4 日よ り茵蔯蒿湯合五苓散料 (煎じ薬) へと変更した。そ の後アルブミン点滴と腹水穿刺を 1 度ずつ行った。 これまではアルブミン投与や腹水穿刺排液の後, 間 もなく腹水貯留が再燃していたが, 茵蔯蒿湯合五苓 散料を開始して以降は徐々に腹囲が減少していた。 体重も右肩下がりとなり，4月18日の時点で体重 $43.4 \mathrm{~kg}$, 腹囲 $69 \mathrm{~cm}$ まで改善し, 以後はプラトーの 状態となり安定した（図 1 )。経過中のAST, ALT, 総ビリルビン (T-Bil)，コリンエステラーゼ $(\mathrm{ChE})$, アルブミン $(\mathrm{Alb})$, クレアチニン $(\mathrm{Cr})$, 血小板 

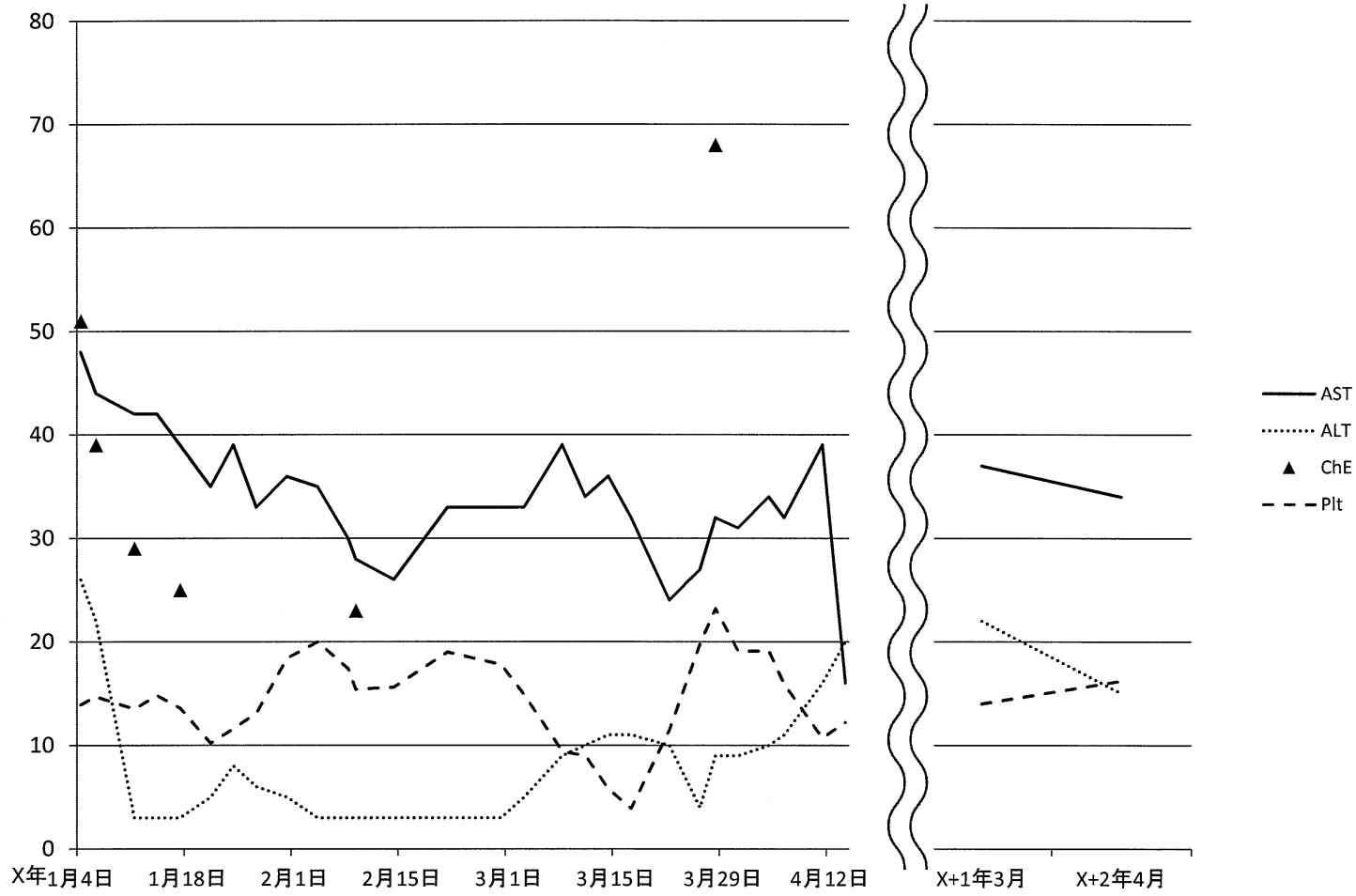

図 2 生化学検查デー夕の推移(1)

総ビリルビン, AST は入院後速やかに改善し基準值を維持できている。ALT，クレアチニン值は 経過中を通して基準值内であった。アルブミンは緩やかな改善が認められたが基準值は大きく下 回っていた。血小板数は変動が大きく、コリンエステラーゼは低值のままであったがわずかに改善 の傾向も認められた。

(Plt）の推移を別に示す（図 2，図 3)。その後 5 月15日の退院に際し茵蔯蒿湯エキス（ツムラ, 7.5 $\mathrm{g} /$ 日）と五苓散エキス（ツムラ， $7.5 \mathrm{~g} /$ 日）併用へ の切り替えとなり, 治療後数年経った平成 27 年 1 月 現在も服薬中であるが，以後は腹水の再発を見てい ない。

\section{考察}

非代償性肝硬変に伴う腹水貯留に対しては, 通常 ループ利尿薬やスピロノラクトンが使用されるが, 大量或いは長期の利尿薬の使用は電解質異常を招き やすく，また肝性脳症などのリスクもある。また低 アルブミン血症に対してはアルブミン補充を行うこ ともあるが，保険診療上の制約もあり医療経済的に も多用できる処置ではない。今回, 漢方を併用し著 しい効果を認め, 治療選択肢の一つとしての有用性 が示唆された結果となった。本症例では入院直後よ りエンテカビルを併用されているが，エンテカビル による HBV-DNA 量の減少から肝機能の改善に至 るまでは一定の期間を要すると考えられる。エンテ カビルの効果について検証した研究についてもその 調査期間は概ね 12 週から 48 週と比較的長期であり ${ }^{122}$,
治療開始後 3 カ月以内での腹水の急速な改善がエン テカビルの効果であるとは考えにくい。なお，図 2 , 図 3 に示すように入院後早期にAST と総ビリルビ ン值の改善が認められているが，これは抗生剤によ る感染症の治療や補液による脱水等全身状態の改善 によるものと考えるほうが自然である。腹水消失後, 長期に安定していることについてはエンテカビルの 効果も含めてのことであることを補足しておく。

本邦に扔いて, 肝硬変に限らず腹水に対する漢方 方剤といえば五苓散加減あるいはその合方が代表的 であるが，その他にも分消湯 ${ }^{3}$ や大建中湯 ${ }^{4}$, 九味檳 榔湯5)などで改善した経験や, 肝癌合併例であるが 防已椒目葶藶大黄丸料(6)有効であった例なども報 告されている。本症例においても, 肝硬変に伴う黄 疸と腹水ということで, 当初は病名漢方的な発想で 茵蔯五苓散料（煎薬）の処方を開始した。しかし, 茵蔯五苓散料（煎薬）あるいは五苓散エキスによっ て症状が改善しないため, 便秘を伴うことと MSSA 敗血症ということで裏に熱があるであろうとの推測 から, 清熱作用と通便作用を期待して茵蔯高湯と五 苓散料の合方としたところ著効を示したものである。 


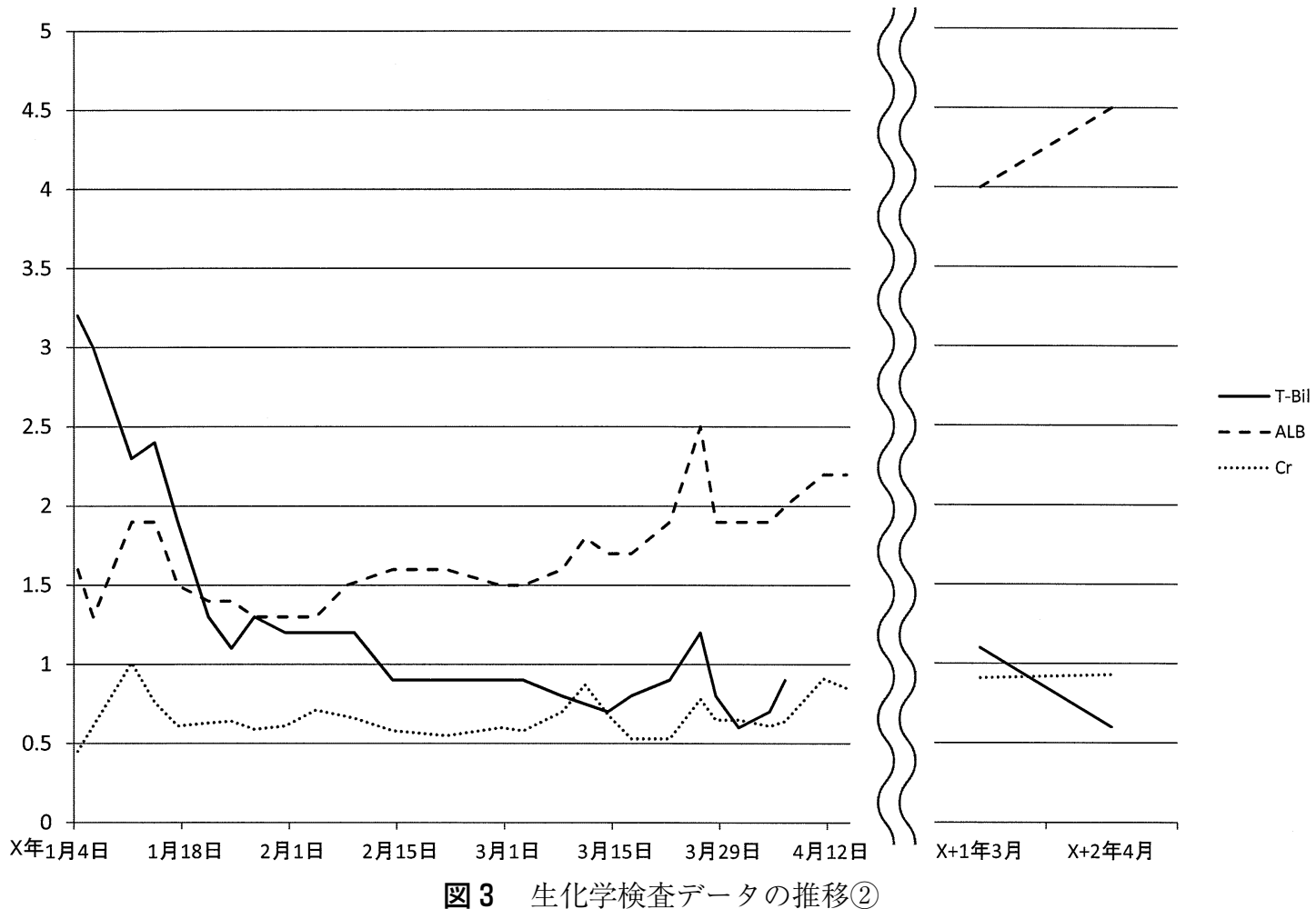

総ビリルビン，AST は入院後速やかに改善し基準值を維持できている。ALT，クレアチニン值は 経過中を通して基準值内であった。アルブミンは緩やかな改善が認められたが基準值は大きく下 回っていた。血小板数は変動が大きく、コリンエステラーゼは低值のままであったがわずかに改善 の傾向も認められた。

茵蔯蒿湯は茵蔯蒿, 大黄, 山梮子の 3 つの生薬で 構成され, 『金實要略』黄疸病脈証抖治第十五に 「穀疸之爲病, 寒熱不食, 食即頭眩, 心胸不安, 久 久發黄, 爲穀疸。茵蔯蒿湯主之。」とあり ${ }^{7)}$, 黄疸に 対する代表方剂として長らく用いられている。また 『傷寒論』辨陽明病脈証扞治第八に陽明病で裏に疼 熱があり黄疸を呈するものに使用せよとある。茵蔯 蒿に含まれる capillarisin は利胆作用を有する他, capillene や capillin 等複数の作用物質と協調して肝 細胞 apoptosis の抑制に働くことで肝細胞保護に働 くことが明らかになっている8 。ラットに茵蔯蒿湯 を投与して肝の線維化の抑制が認められた研究もあ り ${ }^{9)}$ ，慢性肝障害に対する茵蔯蒿湯の有効性が現代 医学的にも少しずつ証明されてきている。

茵蔯蒿湯合五苓散が茵蔯五苓散と異なる点は大黄 と山柧子を含む点であり, 本症例ではこの差が有効 性の差になったのではと考察する。大黄は『薬徵』 に「主通利結毒也。故能治胸満, 腹満, 腹痛, 及便 閉，小便不利。旁治發黄，痳血，腫膿。」とあり ${ }^{10)}$, 中医学的に見ても (1)瀉熱通腸, (2)清熱瀉火・涼血解 毒, (3)行瘀破積, (4)清化湿熱11) とあり, その示すと
ころは概ね一致する。即ち，ただの下剤ではなく， 熱を冷まし疼血や水滞を改善し解毒作用を有する生 薬といえる。本邦では慢性肝障害には柴胡剤や，気 血両虚を考慮して十全大補湯などの補剂がよく使用 される傾向にあるが, 肝硬変のように罹病期間が長 期にわたり，また組織の線維化を伴う場合には駆疼 血剤を併用することがしばしば考慮される。大黄は 前述のように通便作用に伴い瘀血を改善する効果が あるため，より有効であったことが考えられる。一 方，山栃子は同じく『薬徵』において「主治心煩也。 旁治發黄。」とあり，また『本草備要』にまとめら れた記載も心熱を冷まし煩を治す他，黄㾝を改善す るものとされている ${ }^{12)}$ 。中薬学の立場でも概ね同様 に清熱作用をもつ生薬として位置づけられる。基礎 研究においても, 山栃子に含まれる geniposid の代 謝産物である genipin もまた肝細胞の apoptosis の抑 制に働くことで肝細胞保護に働くことがわかってい る9)。本症例ではエンテカビルを併用しており，ま た肝機能やアルブミンがそれほど改善していない段 階から腹水が著明に改善しており, geniposid · genipinの作用が直接的に関与しているかどうかは 
不明である。一方, 山㭛子は genipinによる腸間膜 静脈硬化症の副作用を発症しうるとの報告があり ${ }^{13)}$ 処方に際しては注意が必要である。

本症例は非代償性肝硬変にMSSA による敗血症, 化膿性脊椎炎, 糖尿病と非常に重大な疾患を合併し ていたわけであるが，その割に患者本人は体力があ り元気な方であった。したがって，正気の虚がそれ ほど顕著でなく，むしろ裏熱捛よび瘀血の存在が病 態の中心であったのではないかと推測する。故に, 五苓散のみ, 或いは清熱作用はあるものの茵蔯五苓 散では不十分で, 大黄と山柅子を加え十分に清熱, 駆痁血，通便をはかることで効果があったと考察し た。一方, 茵蔯蒿湯単独でも有効であった可能性も あるが，難症㽽疾を大黄と山栃子で “突き動かす” ことで五苓散の利水効果も生きてくることを期待し, 今回は五苓散をそのまま残すことした。寒熱や虚実 を見極め補瀉のバランスをとることの重要性がよく 経験できた一例である。なお，退院後数年以上にわ たり症状の再発なく，また電解質異常などの問題も なく経過していることもまた漢方治療の素晴らしさ であること申し添えておきたい。

\section{結語}

非代償性肝硬変で西洋医学的治療にて管理の困難 な腹水に対し漢方治療が奏効した一例を報告した。

附記 今回使用した煎薬の構成生薬および産地 茵蓮蒿湯合五苓散料：沢瀉 $6 \mathrm{~g}$ (中国)，获苓 $4.5 \mathrm{~g}$ (中国), 猪苓 $4.5 \mathrm{~g}$ (中国), 白术 $4.5 \mathrm{~g}$ (黒竜江省), 桂皮 $3 \mathrm{~g}$ (ベトナム), 茵蔯蒿 $8 \mathrm{~g}$ (日本), 山栃子 $3 \mathrm{~g}$ (中国), 大黄 $2 \mathrm{~g}$ (中国)

茵陳五苓散料：沢㴼 $6 \mathrm{~g}$ (中国), 猪苓 $5 \mathrm{~g}$ (中国) 获苓 $5 \mathrm{~g}$ (中国), 白术 $5 \mathrm{~g}$ (黒龍江省), 桂皮 $3 \mathrm{~g}$ (ベ
トナム)，茵陳高 $6 \mathrm{~g}$ （日本）

利益相反（COI）に関して開示すべきものなし。

\section{文献}

1) Ye XG, Su QM. Effects of entecavir and lamivudine for hepatitis B decompensated cirrhosis : meta-analysis. World J Gastroenterol 2013 Oct ; 19(39) : 6665-6678.

2) Liaw YF, Raptopoulou-Gigi M, Cheinquer H, et al. Efficacy and safety of entecavir versus adefovir in chronic hepatitis B patients with hepatic decompensation : a randomized, open-label study. Hepatology $2011 ; 54$ : 91100.

3 ）大塚敬節。症候による漢方診療の実際。第 5 版, 南山 堂, 東京 2000. 164-169.

4 ）盛岡頼子. 大建中湯投与後に腹水の消失をみた肝硬変 の 1 例. 日東医誌 $1999 ; 49: 845-849$.

5 ）松崎茂. 漢方エキス剤による治療が奏効した高度の腹 水と浮腫を伴う重症アルコール性肝障害の一例一九味 檳榔湯の運用を中心に一. 日東医誌 $1999 ； 50 ： 261$ 266.

6 ) 木村豪雄. 肝癌に伴う腹水に対する防已椒目葶藶大黄 丸料の一使用経験. 日東医誌 $2003 ; 54: 951-956$.

7 ) 日本漢方協会学術部編. 傷寒雑病論. 東洋学術出版社, 千葉 1981. 169 .

8 ) 持田智. 特集・肝胆膵疾患の漢方治療とエビデンス 基礎的研究一茵蔯蒿湯. 肝胆膵 $2002 ; 44: 335-339$.

9 ) Inao M, Mochida S, Matsui A, et al. Japanese herbal medicine Inchin-ko-to as a therapeutic drug for liver fibrosis. J Hepatol $2004 ; 41: 584-91$.

10）吉益東洞. 薬徵 - 続薬徴. 日本漢方医学研究所, 東京 1980. 145-150.

11）神戸中医学研究会編著. 中医臨床のための中薬学. 東 洋学術出版社, 千葉 2011. 178-180.

12) 汪昂著, 寺師睦宗訓. 臨床百味 本草備要 増訂版. 泰生堂, 東京 1996. 212-214.

13）内藤裕史. 腸間膜静脈硬化症と漢方生薬 - 山栃子との 関係。日本医師会雑誌 $2013 ； 142 ： 585-591$. 